\title{
Pan-filovirus one-step reverse transcription-polymerase chain reaction screening assay
}

\author{
Katharina Kopp ${ }^{1,2,3}$ (D) Ina Smith ${ }^{1}$, Reuben Klein ${ }^{1}$, Shawn $\operatorname{Todd}^{1}$, Glenn A. Marsh ${ }^{1}$, Alister C. \\ Ward $^{2,3}$ \\ ${ }^{1}$ CSIRO Health and Biosecurity, Australian Animal Health Laboratory, Portarlington Rd, Geelong, 3218, Victoria, \\ Australia. \\ ${ }^{2}$ School of Medicine and Centre for Molecular and Medical Research, Deakin University, Waurn Ponds, Victoria \\ 3216, Australia. \\ ${ }^{3}$ Centre for Molecular and Medical Research, Deakin University, Waurn Ponds, Victoria 3216, Australia. \\ Email: katharina.kopp@onehealth-pathogenomics-consulting.org.
}

21 February 2019

\begin{abstract}
Five species within the genera Ebolavirus and Marburgvirus of the family Filoviridae are known to cause severe hemorrhagic fever with high mortality rates in humans and non-human primates. Recent large outbreaks of Ebola virus disease in West Africa (2014 - 2016) and the Democratic Republic of the Congo (2018 - ongoing) have demonstrated the epidemic potential with devastating public health consequences. Several known and novel filovirus species have been found in bats in recent years. However, the role of each virus species in the disease ecology of human disease is still unclear. In particular, the transmission mechanism from potential animal hosts to humans is not known. Therefore, a simple, flexible, cost-effective screening tool for detecting the presence of any (putative) member of the filovirus family in animal samples is needed. In this study, a one-step conventional pan-filovirus RT-PCR assay was developed. The designed universal consensus primers of this screening test target two highly conserved regions of the nucleoprotein (NP) of all currently known filoviruses. The assay was capable of specific amplification of viral RNA of all six primatepathogenic (human and non-human) filovirus species and resulted in 317 bp long RT-PCR products. This amplicon length renders the assay suitable for flexible application as conventional reverse transcription polymerase chain reaction (RT-PCR) as well as for future use as rapid real-time quantitative reverse transcription polymerase chain reaction (RT-qPCR).
\end{abstract}

\section{KEYWORDS}

Filoviridae, Ebolavirus, Marburgvirus, natural host, ecological screening, field surveillance, virus discovery, RT-PCR.

\section{INTRODUCTION}

Five species of the family Filoviridae are known to be pathogenic in humans. Acute infections with the four species Zaire ebolavirus, Sudan ebolavirus, Tai Forest ebolavirus, and Bundibugyo ebolavirus of the genus Ebolavirus and the single species Marburg marburgvirus of the genus Marburgvirus cause severe disease in human patients with often high case fatality rates (Peters \& Khan, 1999, Feldmann \& Geisbert, 2011, Emanuel et al., 2018). While increased bleeding 
tendencies are not necessarily present in all clinical cases infected with these filoviruses (WHO, 1978, Bwaka et al., 1999, Okware et al., 2002, MacNeil et al., 2010, Roddy et al., 2010, Schieffelin et al., 2014, Bah et al., 2015, McElroy et al., 2015, Rougeron et al., 2015, Miraglia et al., 2019), the diseases caused by them are classified under the syndromic cluster of viral hemorrhagic fevers (VHF). Large outbreaks of Ebola virus disease (EVD) caused by Zaire ebolavirus (28,652 cases in West Africa in 2014 - 2016, Bell et al., 2016) and Sudan ebolavirus (425 cases in Uganda in 20002001, Okware et al., 2002) as well as Marburg virus disease (MVD, 252 cases in Angola in 20042005, Towner et al., 2006) have demonstrated the epidemic potential in human populations.

Only in the most recent two outbreaks of EVD in the Democratic Republic of the Congo (Western region April - August 2018 and Eastern region 01 August 2018 - ongoing as of 21 February 2019) a national ethics committee has approved an experimental vaccine and four experimental therapeutics against the Zaire ebolavirus (WHO, 2018a, WHO, 2018b, WHO, 2018c, Ministere de la Sante de RDC, 2018, NIHCC, 2018). Persons at high risk, such as front-line health workers and contacts of patients, are vaccinated. Laboratory-confirmed patients are treated with emergency-approved drugs. Vaccines and treatments have also been developed for diseases caused by the other four human pathogenic filoviruses and some of them have been tested in animal models (Warren et al., 2014, Pittman et al., 2018). However, no officially licensed vaccine or therapy is available today.

This lack of medical countermeasures emphasizes the importance of prevention at the source. A single trans-species spillover event is commonly considered as starting point for consecutive human-to-human transmission chains in Ebola virus disease outbreaks, including the largest epidemic to date (Mylne et al., 2014, Pigott et al., 2014, Gire et al., 2014, Marí Saéz et al., 2015). While this sole spillover mechanism was also assumed for the largest Marburg virus disease epidemic in Angola in 2004 - 2005 (Towner et al., 2006, Pigott et al., 2015), multiple introductions from animal hosts were hypothesized for the second largest MVD outbreak in the Democratic Republic of the Congo in 1998 - 2000 (Bausch et al., 2006, Pigott et al., 2015).

However, there is a major gap in knowledge on the full range of natural reservoir host animals and possible vectors (Caron et al., 2018). The only filovirus species for which a bat species (Egyptian fruit bat, Rousettus aegyptiacus) has been confirmed as natural reservoir host by virus isolation and experimental infection is the Marburg marburgvirus (Towner et al., 2009, Amman et al., 2012, Amman et al., 2014, Paweska et al., 2012, Paweska et al., 2015, Amman et al., 2015). While this finding was the first evidence for the hypothesis that bats play an important role in filovirus disease ecology, it neither revealed the entire host spectrum of this particular filovirus species and the virus family as a whole nor the specific transmission mechanism from an animal host to a human patient. 
Characterization of the Měnglà virus in a fruit bat of the genus Rousettus in China, for which the creation of the novel filovirus genus Dianlovirus was suggested (Yang et al., 2019) is the most recent indicator that bats are natural reservoir hosts of filoviruses. The discovery of a new species member of the genus Ebolavirus, which was named Bombali ebolavirus, in an insectivorous bat species in Liberia (Goldstein et al., 2018) also supports this concept.

Non-human primates and duikers have been found to develop clinical signs of Ebola and Marburg virus disease and also succumb to it (Leroy et al., 2004, Rouquet et al., 2005, Wittmann et al., 2007, Gonzalez et al., 2007, Karesh et al., 2012). Therefore, hunting of sick wildlife and especially collecting dead animals of these species can be assumed as one source of infection for humans. However, large-scale screening of a wide range of animal species ranging from arthropods as potential vectors to vertebrates as reservoir and transmission hosts of filoviruses is necessary in order to cover all possible spillover interfaces with humans.

Several assays employing conventional (RT-PCR) and real-time reverse transcription polymerase chain reaction (RT-qPCR) have been developed for the molecular detection of filoviruses, as reviewed by Clark et al., 2018. Most of these tests were designed for rapid and sensitive laboratory diagnosis and confirmation of clinical disease caused by a previously identified filovirus species. As the majority of these nucleic acid detection assays target distinct sequences of certain filovirus species, they are not suitable for screening a broad range of different virus species in one assay, as would be required for ecological investigations.

With the purpose of reducing the complexity, time and costs of such screenings as well as to facilitate the discovery of novel filoviruses, we aimed for the development of a single molecular assay which can detect all known and possibly novel members of that virus family. As proof of principle for such an approach in screening potential natural hosts for all known and novel filoviruses, it was shown that the developed one-step RT-PCR assay was capable of specific amplification of viral RNA of isolates of Marburg marburgvirus and five species of the genus Ebolavirus in a universal optimized protocol.

\section{MATERIALS AND METHODS}

\section{RNA extraction}

For assay evaluation, viral RNA from Vero E6 culture supernatants of filoviruses, listed in Table 4, were extracted using the QIAamp Viral RNA Mini Kit (catalog-no. 52906, Quiagen, Venlo, the 
Netherlands), as recommended by the manufacturer. Since this treatment renders the sample of negative-sense viral RNA non-infectious, samples were dunked out from the biosafety level 4 (BSL-4) laboratory suite of the Commonwealth Scientific and Industrial Research Organisation (CSIRO) Health and Biosecurity, Australian Animal Health Laboratory, Geelong, Australia, aliquoted in $20 \mu \mathrm{l}$, and stored at $-80^{\circ} \mathrm{C}$ for further investigations.

\section{Oligonucleotide design}

All coding sequences (CDS) of the family Filoviridae (GenBank taxonomic identity 11266), as available on 17 April 2015, were downloaded from the GenBank database (https://www.ncbi.nlm.nih.gov/nuccore/?term=txid11266[Organism:exp]). A parsing script using the term "gene=NP" filtered the respective FASTA file, in order to contain only the nucleoprotein (NP) CDS.

The resulting NP nucleotide sequences were aligned by the standalone version of the multiple sequence alignment (MSA) tool Clustal Omega (https://pkgs.org/download/clustal-omega, version 1.2.4, the web server version can only process input files $<4 \mathrm{MB}$ ) and visualized by the MSA editor and analysis workbench Jalview (Waterhouse et al., 2009). A target region covering a total length of 317 bases of filovirus NP sequences and including two highly conserved areas of 28 nucleotide length at each end was identified by visual inspection of the MSA.

Sequences containing gaps or not clearly identified bases ("N") within the two highly conserved ends of the target region were deleted. Unique sequences of this target area were kept for the design of the universal consensus primers, while identical sequences within this region were removed by using Jalview's "remove redundancy” option. Two sense and two antisense universal consensus primer sequences were designed and chosen for specificity for the family Filoviridae by using the tool Primer-BLAST (https://www.ncbi.nlm.nih.gov/tools/primer-blast/, Ye et al., 2012) and are listed in Table 1.

\section{Conditions of the one-step pan-filovirus RT-PCR assay}

The SuperScript ${ }^{\mathrm{TM}}$ III One-Step RT-PCR System with Platinum ${ }^{\mathrm{TM}}$ Taq DNA Polymerase (catalogno. 12574-026, Invitrogen ${ }^{\mathrm{TM}}$, Thermo Fisher Scientific, Waltham, Massachusetts) was used in the pan-filovirus RT-PCR screening assay. The $20-\mu \mathrm{l}$ assay contained $10 \mu \mathrm{l}$ of $2 \mathrm{X}$ reaction mix provided 
with the kit (including the basic level of $1.6 \mathrm{mM}$ of $\mathrm{MgSO}_{4}$ ), $0.4 \mu \mathrm{l}$ of each of the four $10 \mu \mathrm{M}$ primers (Hyper-NP-FW-1, -FW-2, -REV-1, -REV-2), $0.8 \mu \mathrm{l}$ of SuperScript ${ }^{\mathrm{TM}}$ III RT/Platinum ${ }^{\mathrm{TM}}$ Taq $^{-}$ enzyme mix, and $3.6 \mu \mathrm{l}$ of nuclease-free water (NFW). Finally, for the screening of samples $4 \mu \mathrm{l}$ of extracted RNA was added, for no template controls (NTC) $4 \mu \mathrm{l}$ of NFW, or for positive controls $4 \mu \mathrm{l}$ of in vitro transcribed antisense ssRNA. All reactions were conducted in duplicate.

\section{Cycling profile of the one-step pan-filovirus RT-PCR assay}

The RT-PCR assay involved the following steps: reverse transcription at $50^{\circ} \mathrm{C}$ for 15 min; reverse transcriptase inactivation and hot-start activation at $94^{\circ} \mathrm{C}$ for $2 \mathrm{~min}$; 10 touch-down precycles with $4^{\circ} \mathrm{C}$ for $15 \mathrm{~s}, 68^{\circ} \mathrm{C}$ for $30 \mathrm{~s}$ with a temperature decrease of $1^{\circ} \mathrm{C}$ per cycle (starting at cycle 2 out of 10), and $68^{\circ} \mathrm{C}$ for $1 \mathrm{~min} ; 40$ cycles with $94^{\circ} \mathrm{C}$ for $15 \mathrm{~s}, 60^{\circ} \mathrm{C}$ for $30 \mathrm{~s}$, and $68^{\circ} \mathrm{C}$ for $1 \mathrm{~min}$; and final extension at $68^{\circ} \mathrm{C}$ for $5 \mathrm{~min}$.

\section{Results visualization of the one-step pan-filovirus RT-PCR assay}

The 1\% agarose (UltraPure ${ }^{\mathrm{TM}}$ Agarose, catalog-no. 16500500, Invitrogen ${ }^{\mathrm{TM}}$, Thermo Fisher Scientific Waltham, Massachusetts) gel was cast using 1x SYBR ${ }^{\text {TM }}$ Safe DNA Gel Stain (catalogno. S33102, Invitrogen ${ }^{\mathrm{TM}}$, Thermo Fisher Scientific Waltham, Massachusetts) and $1 \times$ Tris-EDTA buffer (UltraPure ${ }^{\mathrm{TM}}$ DNA Typing Grade ${ }^{\mathrm{TM}}$ 50X TAE Buffer, catalog-no. 24710030, Invitrogen ${ }^{\mathrm{TM}}$, Thermo Fisher Scientific Waltham, Massachusetts). Amplicons generated by the one-step panfilovirus RT-PCR assay were resolved by gel electrophoresis running at 100 volts for an average of 40 minutes, visualized and captured using the Safe Imager $^{\mathrm{TM}} 2.0$ Blue-Light Transilluminator system (catalog-no. G6600EU, Invitrogen ${ }^{\mathrm{TM}}$, Thermo Fisher Scientific Waltham, Massachusetts). The 1 Kb Plus DNA Ladder (catalog-no. 10787018, Invitrogen ${ }^{\mathrm{TM}}$, Thermo Fisher Scientific Waltham, Massachusetts) was used as a marker for estimating the approximate sequence length of PCR products.

\section{Product sequencing of the one-step pan-filovirus RT-PCR assay}

Gel bands of PCR products of samples which were found to have a size approximately corresponding to the 317 bp amplicon, as expected for true positives of all known filovirus sequences (as of 17 April 2015 in the GenBank database, https:/www.ncbi.nlm.nih.gov/nuccore/), 
were excised, purified and prepared for capillary sequencing using the BigDye ${ }^{\mathrm{TM}}$ Terminator v3.1 Cycle Sequencing Kit (catalog-no. 4337455, Applied Biosystems ${ }^{\mathrm{TM}}$, Thermo Fisher Scientific Waltham, Massachusetts). For each resulting amplicon sequence a search over the entire “nucleotide collection (nr/nt)" database by using the "blastn suite” https://blast.ncbi.nlm.nih.gov/ Blast.cgi?PROGRAM=blastn) of the BLAST algorithm (Altschul et al., 1990) was conducted.

\section{In vitro transcription of the antisense ssRNA positive control}

Antisense ssRNA molecules of the full-length nucleoprotein (NP) coding sequence (GenBank ID AF522874, position 464-2683) of the Reston ebolavirus strain Pennsylvania (Groseth et al., 2002) were in vitro transcribed as virus-specific positive controls. While not used as positive controls, also sense ssRNA molecules of the full-length NP CDS of this Reston ebolavirus strain were in vitro transcribed to evaluate if the developed one-step pan-filovirus RT-PCR assay can specifically amplify ssRNA molecules of both directions. The $\sim 2.2 \mathrm{~kb}$ diagnostic target was amplified from a pCAAGGS vector ("pCAGGSEboVRestonNP”) containing the entire NP region by using the primer pair ERp-NP-T7-antisense-FW (5' -TAATACGACTCACTATAGGGTTACTGATGGTGCTGCAAGATTGC-3' ) and Erp-NP-T7-antisense-REV (5'-GTAGGAAAAAGAAGAAGGCATGAACAT-3') or the primer pair ERp-NP-T7-sense-FW (5' -TAATACGACTCACTATAGGGATGTTCATGCCTTCTTCTTTTTCCTAC-3') and ERp-NP-T7-sense-REV (5' -TTACTGATGGTGCTGCAAGATTGC-3' ). Correct length of the PCR products was verified by gel electrophoresis (Figure 1), the corresponding bands excised from the agarose 1\% gel, and purified using the Wizard ${ }^{\circledR}$ SV Gel and PCR Clean-Up System (catalog-no. A9282 Madison, Wisconsin, USA).

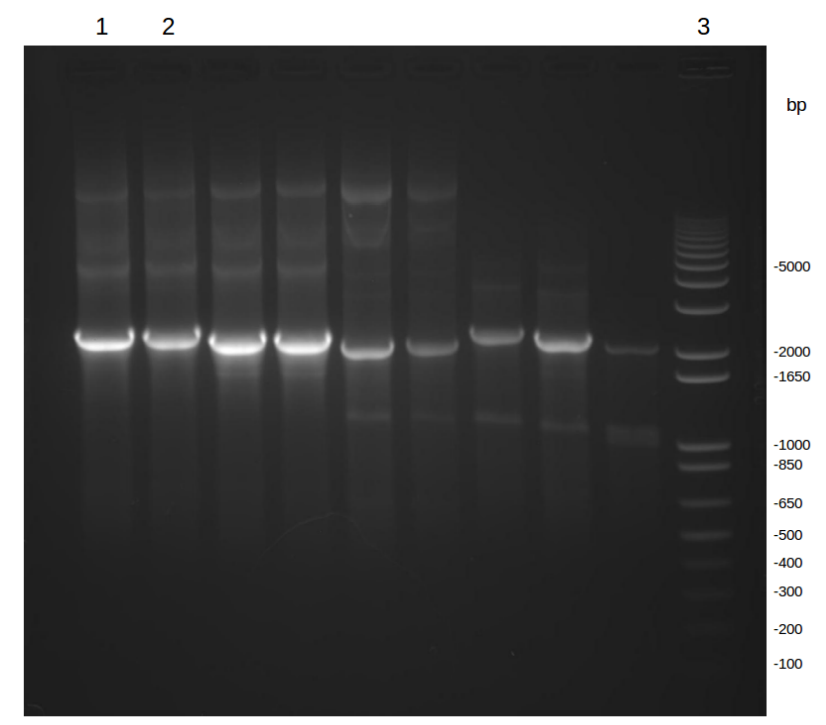


Figure 1: Gel electrophoresis of products of PCR with NP gene- and species-specific primers (lane 1: Erp-NP-T7-antisense-FW and Erp-NP-T7-antisense-REV, lane2: Erp-NP-T7-sense-FW and ErpNP-T7-sense-REV) from circular NP plasmid DNAs. Lane 3: 1kb plus DNA ladder. Non-marked lanes from different experiments (Kopp, 2015, unpublished).

The purified PCR products were used as templates for in vitro transcription of antisense and sense ssRNA by using the HiScribe ${ }^{\mathrm{TM}}$ T7 In Vitro Transcription Kit (NEB \#E2030S, New England BioLabs Inc, Ipswich, Massachusetts, USA). Finally, the in vitro transcribed antisense and sense ssRNA were purified by using the RNeasy ${ }^{\circledR}$ Mini Kit (catalog-no. 74106, Quiagen, Venlo, the Netherlands) including an on-column DNase I digestion step using the RNase-Free DNase Set (catalog-no. 79254, Quiagen, Venlo, the Netherlands). Before being employed as positive controls in the RT-PCR screening of samples for possible detection of filovirus RNA, the concentration of the in vitro transcribed antisense ssRNA control was determined by using the Qubit ${ }^{\mathrm{TM}}$ RNA BR Assay Kit (catalog-no. Q10210, Invitrogen ${ }^{\mathrm{TM}}$, Thermo Fisher Scientific Waltham, Massachusetts) and Qubit ${ }^{\circledR}$ Fluorometer 2.0 as 218 ng/ $\mu$ l.

The presence of the target region of the pan-filovirus RT-PCR assay within the full-length NPcoding sequence of the positive control antisense ssRNA as well as of the sense ssRNA molecule was verified by a Reston ebolavirus-specific RT-PCR employing the primers NP-FW-2 (5'TTTTCAGGACTCCTAATTGTCAAAACCG-3' ${ }^{\prime}$ ) and NP-REV-12 (5'-GCCTCTCTGAGCTGCTGATACTGCTCAC- 3' ) (Figure 2). In addition, the capability of the developed one-step panfilovirus RT-PCR assay (using the primers listed in Table 1) to detect sense and antisense ssRNA was evaluated (Figure 3). The absence of any target region DNA (which might have remained from previous steps in the in vitro RNA-transcription procedure) was verified by non-amplification in a no reverse transcriptase control PCR (minus-RT) reaction using the antisense ssRNA as a template and either the Reston ebolavirus-specific primer pair (Figure 2) or the universal consensus primer pair (Figure 3). Plasmid "pCAGGSEboVRestonNP" served as a positive control template in both minus-RT PCR reactions (Figure 2 and 3). 
Figure 2: Detection of in vitro transcribed ssRNA by conventional one-step RT-PCR using the Reston ebolavirus species-specific primers NP-FW-2 and NP-REV-12 and as a template in vitro transcribed antisense ssRNA (lane2) or sense ssRNA (lane 3). Minus-RT PCR reaction using the species-specific primer pair NP-FW-2 and NP-REV-12 and as a template plasmid “pCAGGSEboVRestonNP” (lane 4) or antisense ssRNA (lane 5). No template control (NTC, lane 6). Marker: $1 \mathrm{~kb}$ plus DNA ladder (lane 1 and 7).

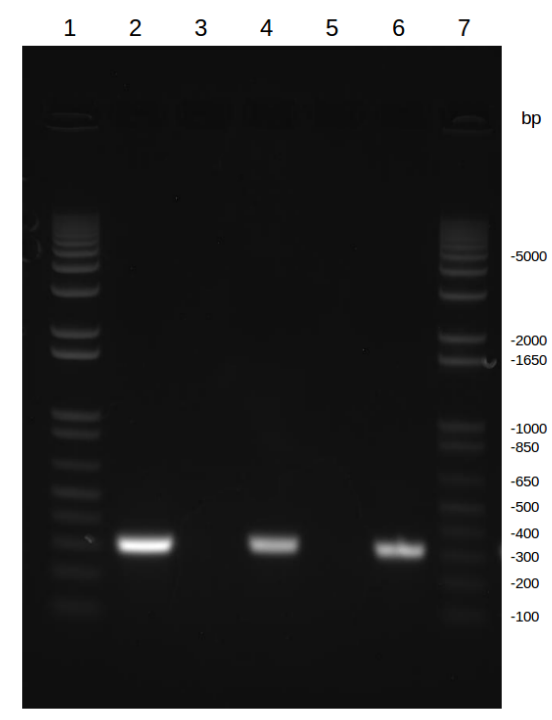

Figure 3: Detection of in vitro transcribed ssRNA by conventional one-step RT-PCR using the universal consensus primers NP-FW-Hyper-1, NP-FW-Hyper-2, NP-REV-Hyper-1, and NP-REVHyper-2 (Table 1) and as a template in vitro transcribed antisense ssRNA (lane 4) or sense ssRNA 
(lane 6). Minus-RT PCR reaction using the universal consensus primers and as a template plasmid “pCAGGSEboVRestonNP” (lane 2) or antisense ssRNA (lane 3). No template control (NTC, lane 5). Marker: $1 \mathrm{~kb}$ plus DNA ladder (lane 1 and 7).

\section{RESULTS}

\section{Design of primers for the one-step pan-filovirus RT-PCR assay}

\begin{tabular}{|c|c|c|}
\hline Name & Sequence (5' $\rightarrow$ 3') & Length \\
\hline NP-FW-Hyper-1 & TTTTCAGGACTATTGATTGTCAAAACAG & 28 \\
\hline NP-FW-Hyper-2 & TTTTCAGGACTTTTGATTGTCAAAACAG & 28 \\
\hline NP-REV-Hyper-1 & GCCTCTCGTAGCTGTTGATATTGTTCGC & 28 \\
\hline NP-REV-Hyper-2 & GCCTCTCGTAGCTGTTGATATTGCTCGC & 28 \\
\hline
\end{tabular}

Table 1: Universal consensus primer set targeting the nucleoprotein region of filoviruses.

The universal consensus primer set of the one-step pan-filovirus RT-PCR assay was developed according to all nucleotide sequences of the nucleoprotein gene of filoviruses as available on 17 April 2015 in the GenBank database (223 sequences). However, because of the large numbers of sequences determined from the Zaire ebolavirus epidemic in West Africa in 2014 - 2016 as well as the discovery of novel putative members of the family Filoviridae, recently, an updated (as of 8 Jan 2019) multiple sequence alignment (MSA) was created as described for the original MSA under Material and Methods. First, the new MSA consisted of 2,219 GenBank sequences spanning the entire target region of the assay. After removal of all sequences which showed ambiguous base calls ("N") or caused gaps in the MSA within the two 28 bases long regions corresponding to the forward and reverse primers, 2,204 and 2,202 sequences remained, respectively. Unique sequences of the target area of the sense and antisense universal consensus primer regions were identified by using Jalview’s “remove redundancy” option.

The target regions of the two sense (NP-FW-Hyper-1 and NP-FW-Hyper-2) and two antisense (NPREV-Hyper-1 and NP-REV-Hyper-2) universal consensus primers correspond to the genome positions 1190-1217 and 1479-1506 (in reverse complement orientation of the antisense primers), respectively, of the Ebola virus isolate “Mayinga, Zaire, 1976” (species: Zaire ebolavirus, GenBank 
ID AF086833.2). Table 2 and 3 display the MSAs of all unique sequence variations found for the target regions of the forward and reverse universal consensus primers.

Each distinct sequence is represented by one GenBank accession. All identical sequences of each distinct variation were found to belong to isolates of the same filovirus species. For the majority of filovirus species (within the genus Ebolavirus: Bombali ebolavirus, Bundibugyo ebolavirus, Reston ebolavirus, Sudan ebolavirus, and Tai Forest ebolavirus; within the genus Cuevavirus: Lloviu cuevavirus), one or two distinct sequences were determined in the target regions of the sense and antisense primers. Two unclassified filoviruses which have recently been discovered in Chinese fruit bat species, the Bat filovirus (GenBank ID KP233864, He et al., 2015) and the Mengla dianlovirus (GenBank ID KX371887, Yang et al., 2017), were also aligned. However, the partial nucleoprotein CDS available for the Bat filovirus does not cover the target region of the sense primer.

More than two unique sequence variations were only found in the forward and reverse primer target regions of the two filovirus species Zaire ebolavirus and Marburg marburgvirus. However, the majority of GenBank entries were identical with only one particular sequence variation. These were 1,803 identical entries out of a total of 2,045 GenBank accessions (88.2\%) in the forward primer target region and 1,925 identical entries out of a total of 2,042 GenBank accessions in the reverse primer target region (94.3\%) for Zaire ebolavirus. The respective figures found for Marburg marburgvirus were 98 identical entries out of a total of 121 GenBank accessions (81.0\%) and 81 identical entries out of a total of 121 GenBank accessions (67.0\%).

\begin{tabular}{|c|c|c|c|}
\hline GenBank ID & Virus species of isolates & $\begin{array}{l}\text { Number of identical } \\
\text { GenBank sequences }\end{array}$ & $\begin{array}{l}\text { Target region of NP-FW-Hyper-1/2 } \\
\text { (position 1190-1217 of AF086833.2) }\end{array}$ \\
\hline & Genus Ebolavirus & & \\
\hline NC_039345.1 & Bombali ebolavirus & 3 & $\cdots \cdots \cdot \mathrm{CT}_{\mathrm{CT}} \cdot \mathrm{G} \cdot \mathrm{C} \cdot \mathrm{C}$ \\
\hline KU182911.1 & Bundibugyo ebolavirus & 4 & $\cdots \mathrm{C} \cdot \mathrm{C} \cdots \mathrm{T} \cdot \mathrm{G} \cdots \cdot \mathrm{A} \cdot \boldsymbol{}$ \\
\hline KY008770.1 & Reston ebolavirus & 7 & $\cdots \cdots \cdots \cdots C_{C C} \cdot A \cdot \cdots \cdots \cdots \cdot C \cdot$ \\
\hline MF540570.1 & Reston ebolavirus & 2 & $\cdots \cdot{ }_{G} \cdots \cdots \cdot C C \cdot A \cdot \cdots \cdots \cdot C \cdot$ \\
\hline MH121162.1 & Sudan ebolavirus & 16 & $\cdots \mathrm{C} \cdot \mathrm{T} \cdot \mathrm{T} \cdots \mathrm{C} \cdots \cdots \boldsymbol{A}_{\mathrm{A}} \cdot{ }_{\mathrm{G}} \cdot \boldsymbol{T}_{\mathrm{T}} \cdot$ \\
\hline MH121167.1 & Tai Forest ebolavirus & 4 & $\cdots$ \\
\hline MG572229.1 & Zaire ebolavirus & 1803 & \\
\hline
\end{tabular}




\begin{tabular}{|c|c|c|c|}
\hline MG572235.1 & Zaire ebolavirus & 216 & $\cdots \cdots \cdots$ тт $\cdots \cdots \cdots \cdots \cdots$ \\
\hline MH121166.1 & Zaire ebolavirus & 19 & $\cdots \cdots \cdots$ ст $\cdots \cdots \cdots \cdots \cdots \cdots$ \\
\hline KR105337.1 & Zaire ebolavirus & 3 & $\cdots \cdots \cdots \mathrm{T}_{\mathrm{T}} \cdots \mathrm{c} \cdots \cdots \cdots \cdots \cdots$ \\
\hline KU296744.1 & Zaire ebolavirus & 2 & $\cdots \cdots \cdots c \cdots \cdots \cdots \cdots \cdots \cdots \cdots \cdots \cdots$ \\
\hline КР759633.1 & Zaire ebolavirus & 1 & $\cdots \mathrm{c} \cdots \cdots \boldsymbol{T}_{\mathrm{m}} \cdots \cdots \cdots \cdots \cdots \cdots \cdots$ \\
\hline \multirow[t]{2}{*}{ KR817076.1 } & Zaire ebolavirus & 1 & $\cdots \cdots \cdots \cdot \cdots \cdots \cdots \cdots \cdots \cdots \cdots$ \\
\hline & Genus Marburgvirus & & \\
\hline MF939097.1 & Marburg marburgvirus & 98 & $\cdots \mathrm{c} \cdots \cdots \cdot \mathrm{c} \cdot \mathrm{T} \cdot \cdots \cdot \mathrm{G} \cdot \cdots \cdots$ \\
\hline KU059750.1 & Marburg marburgvirus & 19 & $\cdots \mathrm{C} \cdots \boldsymbol{G}_{\mathrm{G}} \cdots \mathrm{C} \cdot \mathrm{T} \cdots \cdots \mathrm{G} \cdots \cdots$ \\
\hline \multirow[t]{2}{*}{ DQ217792.1 } & Marburg marburgvirus & 4 & $\cdots \mathrm{C} \cdots \cdots \cdot \mathrm{C} \cdot \mathrm{T} \cdot \mathrm{C} \cdot \mathrm{G}_{\mathrm{G}} \cdots \cdots$ \\
\hline & Genus Cuevavirus & & \\
\hline \multirow[t]{2}{*}{ NC_016144.1 } & Lloviu cuevavirus & 1 & $\cdots \cdots \cdots \cdot{ }_{T} \cdot G \cdot A \cdot C \cdot G \cdot G \cdot T \cdot$ \\
\hline & Unclassified Filovirida & & \\
\hline \multirow[t]{2}{*}{ KX371887.2 } & Mengla dianlovirus & 1 & $\cdots \mathrm{C} \cdots \cdots \cdot \mathrm{GC} \cdots \cdots \mathrm{A} \cdot \boldsymbol{G}_{\mathrm{G}} \cdot \mathrm{T} \cdot$ \\
\hline & Sense universal consen & & \\
\hline NP-FW-Hyper-1 & & & TTTTCAGGACTATTGATTGTCAAAACAG \\
\hline NP-FW-Hyper-2 & & & $\cdots \cdots \cdots \underline{T}_{\underline{T}} \cdots \cdots \cdots \cdots \cdots$ \\
\hline
\end{tabular}

Table 2: Target region of the designed universal consensus forward primers (NP-FW-Hyper-1 and NP-FW-Hyper-2) of the one-step pan-filovirus RT-PCR assay. All sequences of the target region available from the GenBank database were aligned and processed as described in the section Material and Methods. Every type of unique sequence variation in this region is represented by a GenBank accession number (column 1) and the filovirus species assigned to all GenBank entries of the identical sequence (column 2). The number of GenBank accessions (column 3) found for each unique sequence variant (column 4) is listed. Dots indicate sequence positions matching with that of the two sense universal consensus primer variants. Mismatches are represented by the base in the unique sequence variant. The two different positions of the two primers are underlined. 
bioRxiv preprint doi: https://doi.org/10.1101/579458; this version posted March 16,2019 . The copyright holder for this preprint (which was

not certified by peer review) is the author/funder, who has granted bioRxiv a license to display the preprint in perpetuity. It is made available under aCC-BY-NC-ND 4.0 International license.

\begin{tabular}{|c|c|c|c|}
\hline GenBank ID & Virus species of isolates & $\begin{array}{l}\text { Number of } \\
\text { identical } \\
\text { GenBank } \\
\text { sequences }\end{array}$ & $\begin{array}{l}\text { Target region of NP-REV-Hyper-1/2 } \\
\text { (position 1479-1506 of AF086833.2) }\end{array}$ \\
\hline & Genus Ebolavirus & & \\
\hline MF319185.1 & Bombali ebolavirus & 2 & $\cdot \mathrm{T} \cdots \cdots \mathrm{G} \cdot \mathrm{C} \cdots \cdots \cdot \mathrm{CA} \cdot \mathrm{G} \cdots \cdots$ \\
\hline MF319186.1 & Bombali ebolavirus & 1 & $\cdots \cdots \cdot \cdot C \cdot \cdots \cdots \cdot C A \cdot G \cdot \cdots$ \\
\hline KR063673.1 & Bundibugyo ebolavirus & 4 & $\cdot A \cdots A C \cdot \cdots \cdot A \cdot G \cdots \cdots A \cdots$ \\
\hline MF540571.1 & Reston ebolavirus & 8 & $\cdot \mathrm{T} \cdots \cdot \mathrm{G}_{\mathrm{G}} \cdots \mathrm{G}_{\mathrm{G}} \cdots \mathrm{T}_{\mathrm{TA}} \cdots \cdots$ \\
\hline JX477165.1 & Reston ebolavirus & 1 & $\cdot \mathrm{T} \cdots \mathrm{G}_{\mathrm{G}} \cdots \mathrm{G}_{\mathrm{G}} \cdots \mathrm{CA}_{\mathrm{C}} \cdots \cdots$ \\
\hline KT750754.1 & Sudan ebolavirus & 14 & $\cdot G \cdots \cdots \cdots \cdot G \cdot A \cdot G \cdot{ }^{T} \cdots \cdots$ \\
\hline MH121169.1 & Sudan ebolavirus & 2 & $\cdot G \cdots \cdots \cdots \cdot_{G} \cdot A \cdots \cdots T_{T} \cdots \cdots$ \\
\hline KU182910.1 & Tai Forest ebolavirus & 4 & $\cdot G \cdot \cdots \cdot_{G} \cdots \cdot_{G} \cdot A \cdots \cdots \cdot A \cdot$ \\
\hline KU296596.1 & Zaire ebolavirus & 1925 & $\cdot A \cdots \cdots \cdot \cdots \cdots \cdot C A \cdots \cdots$ \\
\hline AY058895.1 & Zaire ebolavirus & 93 & $\cdot A \cdots \cdot G \cdots \cdots \cdot A \cdot C A \cdots \cdots$ \\
\hline KU296553.1 & Zaire ebolavirus & 11 & $\cdot \mathrm{A} \cdots \cdots \mathrm{G} \cdots \cdots \cdot \mathrm{TA} \cdots \cdots$ \\
\hline KU296580.1 & Zaire ebolavirus & 7 & $\cdot \mathrm{A} \cdots \cdots \cdot \mathrm{GC} \cdots \cdots \cdot \mathrm{CA} \cdots \cdots$ \\
\hline KR105261.1 & Zaire ebolavirus & 2 & $\cdot A \cdots G_{G} \cdots C_{G} \cdots C_{C A} \cdots \cdots$ \\
\hline KT765130.1 & Zaire ebolavirus & 1 & $\cdot A \cdots \cdots G \cdots \cdots \cdot G \cdot C A \cdots \cdots$ \\
\hline KU296669.1 & Zaire ebolavirus & 1 & $\cdot A \cdots \cdots \cdots \cdots \cdot C A \cdots \cdots$ \\
\hline KY785949.1 & Zaire ebolavirus & 1 & $\cdot \mathrm{A} \cdots \cdots \cdot \mathrm{G} \cdots \cdots \cdot \mathrm{T} \cdot \mathrm{CA} \cdots \cdots$ \\
\hline KY785965.1 & Zaire ebolavirus & 1 & $\cdot \mathrm{A} \cdots \cdot \mathrm{G} \cdots \cdots \cdot \mathrm{CA} \cdots \cdots \mathrm{T}^{\mathrm{T}}$ \\
\hline
\end{tabular}

\section{Genus Marburgvirus}

DQ447660.1

FJ750953.1

JX458858.1

NC_001608.3

JX458831.1

KP985768.1

EU068109.1
Marburg marburgvirus

Marburg marburgvirus

81

19

Marburg marburgvirus

12

Marburg marburgvirus

4

Marburg marburgvirus

2

Marburg marburgvirus

2

Marburg marburgvirus
1 


\section{Genus Cuevavirus}

\begin{tabular}{|c|c|c|c|}
\hline NC_016144.1 & Lloviu cuevavirus & 1 & $\cdot \mathrm{T} \cdots \cdots \cdot \mathrm{C} \cdot \mathrm{G} \cdot \mathrm{A} \cdot \mathrm{C} \cdot \cdots \cdots$ \\
\hline & Unclassified Filovir & & \\
\hline KP233864.1 & Bat filovirus & 1 & $\cdot \mathrm{T} \cdots \cdots \mathrm{T} \cdots \mathrm{CAT} \cdot \mathrm{G} \cdot \mathrm{T}_{\mathrm{T}} \cdot \mathrm{A} \cdots$ \\
\hline \multirow[t]{2}{*}{ KX371887.2 } & Mengla dianlovirus & 1 & $\cdot A \cdots \cdot G \cdots \cdots \cdot A \cdots \cdot G \cdot A \cdots$ \\
\hline & Antisense universal & rim & \\
\hline NP-REV-Hyper-1 rc & & & GCGA杰AATATCAACAGCTACGAGAGGC \\
\hline NP-REV-Hyper-2 rc & & & $\cdots \underline{G} \cdots \cdots \cdots$ \\
\hline
\end{tabular}

Table 3: Target region of the designed universal consensus reverse primers (NP-REV-Hyper-1 and NP-REV-Hyper-2, here shown as reverse complement) of the one-step pan-filovirus RT-PCR assay. Legend and details as described in the caption of Table 2.

\section{Optimization of reaction and cycling conditions of the one-step pan-filovirus RT- PCR assay}

An optimal final primer concentration of $0.4 \mu \mathrm{M}$ was determined for each of the four universal consensus primers (Hyper-NP-FW-1, Hyper-NP-FW-2, Hyper-NP-REV-1, and Hyper-NP-REV-2) in a reaction by titration experiments, in comparison to the sensitivity of the assay when the Reston ebolavirus-specific primer pair was used at the (manufacturer-recommended) constant concentration of $0.2 \mu \mathrm{M}$. For this purpose, five different concentrations $(0.15 \mu \mathrm{M}, 0.2 \mu \mathrm{M}, 0.3 \mu \mathrm{M}$, $0.4 \mu \mathrm{M}$, and $0.5 \mu \mathrm{M}$ ) of each of the two sense primers (Hyper-NP-FW-1 and Hyper-NP-FW-2) were simultaneously tested versus these five distinct concentrations of each of the two antisense primers (Hyper-NP-REV-1 and Hyper-NP-REV-2). These 5 x $5=25$ reaction set-ups were examined in triplicate in detecting the in vitro transcribed positive control ssRNA in a 10-fold dilution series from $872 \mathrm{ng}$ to $8.72 \mathrm{fg}$ per reaction.

None of the reactions containing the 25 different combinations of concentrations of the universal consensus primer quadruplet produced a visible amplicon band in the following gel electrophoresis at a template concentration of $8.72 \mathrm{fg}$, which corresponds to $\sim 7,360$ copies of the $\sim 2.2 \mathrm{~kb}$ ssRNA positive control template. Only one out of the three identical reactions which employed the $200 \mathrm{nM}$ 
concentration of the virus-specific primer pair (NP-FW-2 and NP-REV-12) were found to give a specific amplicon signal in the gel electrophoresis at that template concentration.

The estimated limit of detection (LOD) was defined as the lowest ssRNA amount of the dilution series for which positive detection in all three identical reactions could be determined. For the assay using the virus-specific primer pair, the LOD was found to be $87.2 \mathrm{fg}$ (or 73,600 copies) of the positive control ssRNA per reaction. The LOD value for the virus-specific primer pair assay was only reached by the reactions containing the $400 \mathrm{nM}$ concentration of each of the four universal consensus primers, which was, therefore, considered as optimal final primer concentration of the pan-filovirus assay.

Analogously, the highest annealing temperature (in the 40 cycles after the 10 touch-down precycles) which was found to achieve the same sensitivity for the reactions using the four universal consensus primers (Hyper-NP-FW-1, Hyper-NP-FW-2, Hyper-NP-REV-1, and Hyper-NP-REV-2) and for the reactions using the positive-control-specific primer pair (NP-FW-2 and NP-REV-12) was $60^{\circ} \mathrm{C}$.

\section{Specific amplification of viral RNA of isolates of Marburg marburgvirus and five species of the genus Ebola virus by the one-step pan-filovirus RT-PCR assay}

Using the above-described reaction conditions and cycling profile, the developed pan-filovirus RTPCR assay detected viral RNA extracted from Vero E6 cell culture virus isolates shown in Table 4. As the end-point RT-PCR pan-filovirus assay developed in this study, served as a first proof-ofprinciple application aiming for the future development of corresponding reverse transcription quantitative real-time PCR (RT-qPCR) pan-filovirus assays, specific amplification of viral RNA was conducted only with unquantified RNA extracts from virus cell culture supernatants (undiluted, and ten-fold dilutions from $10^{-1}$ to $10^{-6}$ ). 
bioRxiv preprint doi: https://doi.org/10.1101/579458; this version posted March 16, 2019. The copyright holder for this preprint (which was not certified by peer review) is the author/funder, who has granted bioRxiv a license to display the preprint in perpetuity. It is made available under aCC-BY-NC-ND 4.0 International license.

\begin{tabular}{|c|c|c|c|}
\hline Genus & Species & Virus isolate & GenBank ID \\
\hline \multirow[t]{9}{*}{ Ebolavirus } & Bundibugyo ebolavirus & Bundibugyo 2007 & FJ217161 \\
\hline & Taï forest ebolavirus & Cote d'Ivoire 1994 & FJ217162 \\
\hline & \multirow[t]{2}{*}{ Reston ebolavirus } & Pennsylvania 1989 & AF522874 \\
\hline & & Philippines 2009 & JX477165 \\
\hline & \multirow[t]{2}{*}{ Sudan ebolavirus } & Boniface 1976 & FJ968794 \\
\hline & & Gulu 2000 & AY729654 \\
\hline & \multirow[t]{3}{*}{ Zaire ebolavirus } & Mayinga 1976 & AF086833 \\
\hline & & Kikwit 1995 & JQ352763 \\
\hline & & Makona 2014 & KR781609 \\
\hline \multirow[t]{3}{*}{ Marburgvirus } & \multirow[t]{3}{*}{ Marburg marburgvirus } & Musoke 1980 & DQ217792 \\
\hline & & Ravn 1987 & DQ447649 \\
\hline & & Angola 2005 & DQ447660 \\
\hline
\end{tabular}

Table 4: Virus isolates for which the developed pan-filovirus RT-PCR assay detected the presence of viral RNA.

RNA extracts of all virus isolates and their dilutions down to $10^{-4}$ showed specific amplification in gel electrophoresis analysis for all virus species examined (Table 4). As an example, Figure 4 displays the detection of viral RNA from a virus isolate of the Angola 2005 strain of the Marburg marburgvirus (GenBank ID Q447660) by the one-step pan-filovirus RT-PCR assay. The specific nucleotide sequence of the 317 bp PCR product of each virus isolate, which had been purified from the agarose gel, was verified by Sanger sequencing and BLAST analysis. Extracted viral RNA of Hendra virus, Nipah virus, Measles virus, Rabies virus, Australian bat lyssavirus, and Borna virus were provided by high-containment laboratory groups of CSIRO Health and Biosecurity, Australian Animal Health Laboratory, Geelong, Australia and did not show specific amplification in the developed pan-filovirus RT-PCR assay. 


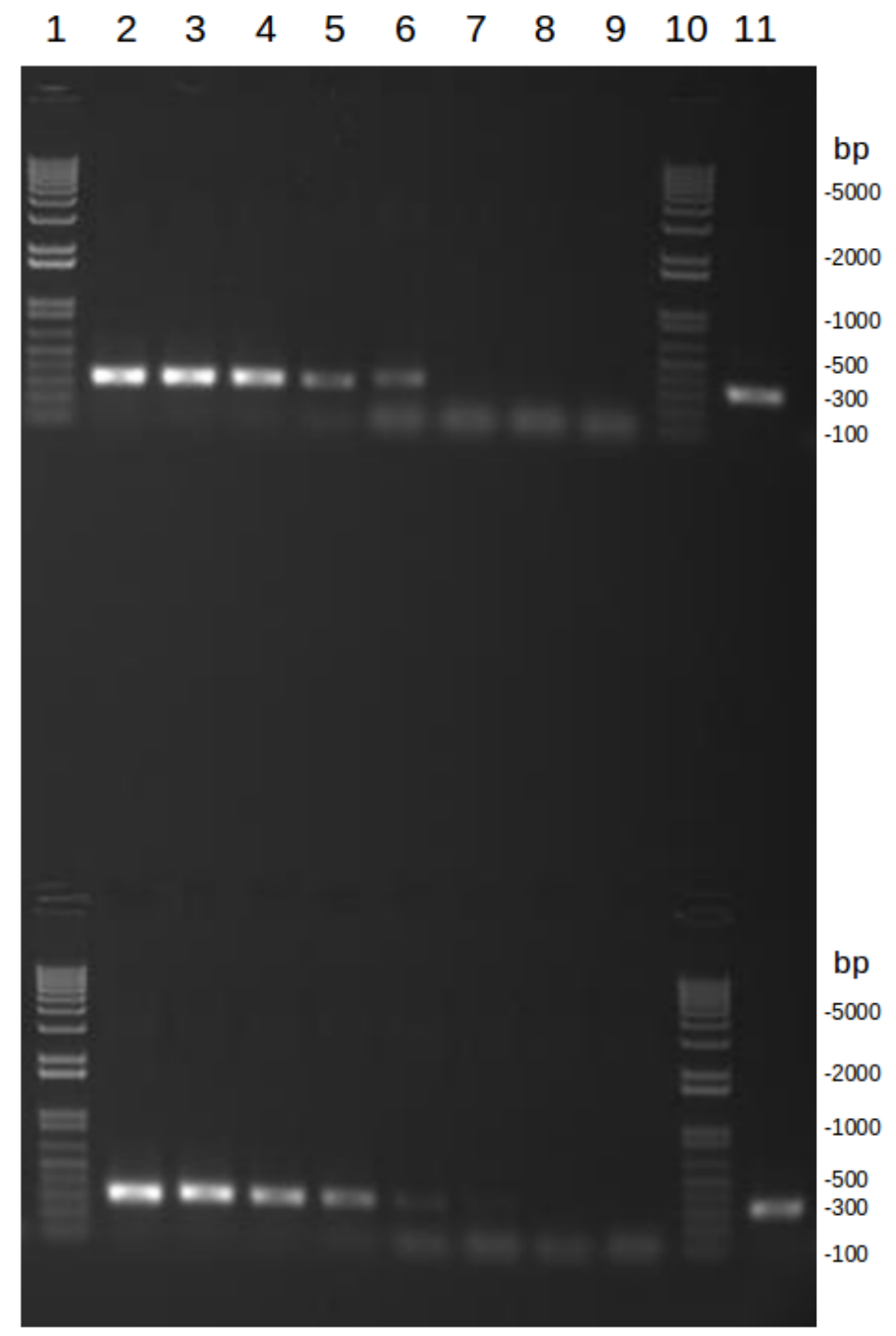

Figure 4: Detection of viral RNA extracted from a virus isolate of the Angola 2005 strain of the Marburg marburgvirus (GenBank ID Q447660) cell culture supernatant by conventional one-step RT-PCR using the universal consensus primers NP-FW-Hyper-1, NP-FW-Hyper-2, NP-REV-Hyper1, and NP-REV-Hyper-2 (Table 1). Undiluted viral RNA extract (lane 2), dilutions $10^{-1}$ to $10^{-6}$ (lane 2 to 8), no template control (NTC, lane 9), and positive control using $~ 8.72$ pg of in vitro transcribed antisense ssRNA NP of Reston ebolavirus (lane 11). All reactions in duplicate. Marker: $1 \mathrm{~kb}$ plus DNA ladder (lane 1 and 10).

\section{DISCUSSION}

The one-step pan-filovirus RT-PCR assay developed in this study provides a robust and broad first screening tool in determining if an animal sample contains viral RNA of a known or unidentified 
putative member of the family Filoviridae. The universal consensus primer pairs of this RT-PCR target two highly conserved regions within the nucleoprotein gene. According to this primer design, the multiple alignment analysis (Table 2 and 3) indicates that specific amplicons could be expected not only from the 12 tested virus isolates (Table 4) but also when viral RNA of most, if not all, currently known members of the family Filoviridae are used as a template. In line with these bioinformatics findings, the developed RT-PCR assay produced specific amplicons of $317 \mathrm{bp}$ length of the nucleoprotein coding region of the viral genomes, when used for testing viral RNA extracts of 12 distinct virus isolates spanning six filovirus species (Table 4).

Therefore, the products of these RT-PCR reactions could serve as appropriate sequencing templates in attempts to identify the filovirus species or strain in a sample. This is important, as for several distinct virus species and lineages of the genus Ebolavirus and Marburgvirus more specific and sensitive tests, such as reverse transcription quantitative real-time PCR (RT-qPCR) assays are available (Gibb et al., 2001, Drosten et al., 2002, Weidmann et al., 2004, Towner et al., 2004, Trombley et al., 2010, U.S. FDA, 2014, Pinsky et al., 2015, Southern et al., 2015, WHO, 2015, TIB MolBiol \& Roche, n.d., Cnops et al., 2016, Rieger et al., 2016, Semper et al., 2016, Loftis et al., 2017, Pettitt et al., 2017). Overall, with hundreds of viral genome copies or less, the limit of detection (LOD) of each of these real-time RT-qPCR tests (Clark et al., 2018) is around two orders of magnitude lower than that ( 73,600 copies) found for the end-point RT-PCR developed in this study. The determined sequence of the amplicons could also inform the design of exactly matching primers (and probes, depending on the applied assay chemistry) for the development of more specific and sensitive follow-up nucleic acid detection assays.

Diagnosis and confirmation to investigate clinical samples in a human epidemic caused by an identified single filovirus and ecological screening of potential animal hosts for any member of this virus family require different methodological approaches. Several established real-time RT-PCR (RT-qPCR) systems are considered as "gold standard” in diagnosing filovirus infections in human patients. They, therefore, have been approved by the U.S. Food and Drug Administration (FDA) as methods of choice, in ongoing outbreak situations, mainly when the species or strain of the causative agent is known. As all of these methods target specific regions of one or more filovirus species whose nucleotide sequences had been determined at the time of the assays' development, they are expected to be capable of reliably detecting only certain filovirus species.

As shown in the outbreak of the then unknown Bundibugyo ebolavirus in Western Uganda in 2007, using RT-(q)PCR assays, originally developed for different species or lineages of the virus family Filoviridae, can lead to $100 \%$ false-negative results (Towner et al., 2008). Only after virus isolation 
from patients and consecutive whole-genome sequencing a highly sensitive and specific RT-qPCR test was developed (Towner et al., 2008) and successfully applied in the control of the epidemic by correct patient identification, quarantine, and supportive treatment. The described management of this outbreak probably considerably contributed to its limited extent in duration and space compared with other previous filovirus epidemics but might have been implemented just in time. The initial complete failure of tests based on certain filovirus species in this case, demonstrated that even having a panel of highly specific molecular detection methods at hand might be insufficient in dealing with novel and emerging pathogens promptly.

However, as experienced in the largest Ebola virus disease epidemic in West Africa in 2014 - 16 (Marí Saéz et al., 2015), spillovers from a yet not unambiguously identified reservoir host into the human population have always started in a remote region of peri-equatorial Africa and must ideally be curbed at their source of origin. As witnessed in the warning example of the Bundibugyo ebolavirus outbreak in 2007 (Towner et al., 2008), developing an appropriate molecular detection method requires virus isolation and full-length sequencing of at least the RT-qPCR's target region. These prerequisites demand sophisticated and high-containment (BSL-4) laboratory facilities and trained personnel, which might not be fast available, especially in resource-limited and remote areas.

While full-length genome sequencing and isolation from tissue culture are mandatory as final confirmation procedures for correct taxonomic classification of a potential filovirus and facilitating further research on diagnostics, treatment, and prevention, these rather complicated methods are not fast and robust enough for filovirus identification and discovery in the field. A broad range of detection capability at virus family level is needed for the first line of defense diagnostics in remote not yet identified outbreaks as well as in the search for the potential reservoir and transmission hosts. To close this gap, we developed a one-step RT-PCR assay which facilitates the screening of samples for the entire filovirus family in a simple, cost-effective “one-fits-all” protocol.

Three assays, two conventional RT-PCR tests (Sanchez et al., 1999, Zhai et al., 2007) and a realtime RT-qPCR test (Panning et al., 2007, partially using primers from Sanchez et al., 1999) also attempted to achieve this aim by targeting the L gene, which encodes the RNA-dependent RNA polymerase of filoviruses (Feldmann et al., 1993). However, the design of the consensus primer sets of all three assays had been based on the L gene sequences of all known filovirus species before the discovery of the Bundibugyo ebolavirus in 2007. However, a following modified version of the real-time RT-qPCR, initially developed by Panning et al., 2007, was found capable of detecting all human-pathogenic filoviruses known by 2016 (Rieger et al., 2016). 
Like the assay developed in this study, the test designed by Ogawa et al., 2011 is a conventional pan-filovirus one-step RT-PCR, and its four primers (two sense and two antisense primers) target the nucleoprotein gene. The two assays differ in the number of available sequences their design had been based on and the length of their PCR product.

On the 17 November 2010, the date of the online publication by Ogawa et al., 2011, only 45 sequences of the nucleoprotein (NP) coding region of filoviruses were deposited in the GenBank database. In contrast, at the time of the primer design (17 April 2015) of the one-step pan-filovirus RT-PCR assay presented in this study 223 NP nucleotide sequences were available in GenBank. Mainly due to a large number of new sequences determined during the EVD epidemic in West Africa in 2014 - 2016 even almost ten times more NP sequences $(2,219)$ could be found in the GenBank database for the multiple sequence alignment analysis of the designed universal consensus primer pairs (Table 2 and 3).

Specific amplification of the targeted NP sequence in a filovirus genome yields a PCR product in the assay of this study and the test developed by Ogawa et al., 2011 of 317 bp and 594 bp, respectively. The advantage of a longer amplicon (594 bp) produced by the Ogawa et al., 2011 test for species identification and virus discovery might be outweighed by the suitability of a shorter PCR product (317 bp), gained in the assay presented in this study, for further development of a dyebased real-time RT-qPCR. First applications of the assay as dye-based one-step real-time RT-qPCR, using the same universal consensus primer set, reaction and cycling conditions as designed and optimized for the conventional RT-PCR test, showed promising outcomes in increased sensitivity, real-time visualization of results, and rapid verification of specific amplicons by high resolution melt analysis (Kopp, 2015, unpublished).

Direct comparison of these previously developed RT-(q)PCR tests and the new pan-filovirus RTPCR assay concerning sensitivity and specificity has not been possible. Templates of different origins, such as in vitro transcribed RNA, total RNA extracts of infected cell cultures, blood or tissues of animal models or human patients, were used in evaluating these assays. In addition, the sensitivity was measured in different units, such as RNA copies per assay or plaque- or focusforming units in infected cell cultures. Furthermore, various sets of pathogens relevant for differential diagnosis of viral hemorrhagic fevers were employed in determining the specificity of each assay.

However, it would be beneficial to have at least two RT-PCR assays with high sensitivity and specificity each targeting a different gene of filovirus genomes. The gained complementary PCR 
products would allow the first confirmation of positive detection results already during the screening process of large ecological sample sets with RT-PCR assays before more time-consuming and expensive follow-up sequencing. Therefore, a systematic evaluation procedure of all currently available pan-filovirus RT-PCR assays using a standard set of specific and unspecific templates ranging from in vitro transcribed RNA to samples of infected animals and human patients as well as a consistent method of sensitivity measurement seems essential.

In this study, the optimization and proof-of-principle of the developed one-step pan-filovirus RTPCR assay were conducted under sets of standardized conditions in the laboratory, which could be controlled one-by-one. However, the real-life robustness, applicability, and accuracy of this assay will have to be evaluated in the field. When applied to large scale ecological investigations into the range of potential natural hosts of filoviruses, it could be assumed that not all factors, such as source, quality, acquisition, handling, transport, and storage of the samples can be controlled at all times, especially in low resource settings of remote regions. The laboratory facilities in which the RNA extraction and RT-PCR will be performed might be of sub-standard and lack essential infrastructure and must cope with frequent power dips and error sources, such as crosscontamination by previous experiments. The actual feasibility, practicability, and ease of usage by minimally trained staff with limited resources at hand will have to be tested under field conditions. The final purpose of this test will only be achieved when it will be applied in large-scale ecological studies, which aim at finding the natural reservoir and transmission hosts of filoviruses.

\section{REFERENCES}

Altschul SF, Gish W, Miller W, Myers EW, Lipman DJ. Basic local alignment search tool. J Mol Biol. 1990 Oct 5;215(3):403-10. PubMed PMID: 2231712.

Amman BR, Carroll SA, Reed ZD, Sealy TK, Balinandi S, Swanepoel R, Kemp A, Erickson BR, Comer JA, Campbell S, Cannon DL, Khristova ML, Atimnedi P, Paddock CD, Crockett RJ, Flietstra TD, Warfield KL, Unfer R, Katongole-Mbidde E, Downing R, Tappero JW, Zaki SR, Rollin PE, Ksiazek TG, Nichol ST, Towner JS. Seasonal pulses of Marburg virus circulation in juvenile Rousettus aegyptiacus bats coincide with periods of increased risk of human infection. PLoS Pathog. 2012;8(10):e1002877.

Amman BR, Nyakarahuka L, McElroy AK, Dodd KA, Sealy TK, Schuh AJ, Shoemaker TR, Balinandi S, Atimnedi P, Kaboyo W, Nichol ST, Towner JS. Marburgvirus resurgence in Kitaka Mine bat population after extermination attempts, Uganda. Emerg Infect Dis. 2014 Oct;20(10):1761-4. doi: 10.3201/eid2010.140696. PubMed PMID: 25272104; PubMed Central PMCID: PMC4193183. 
Amman BR, Jones ME, Sealy TK, Uebelhoer LS, Schuh AJ, Bird BH, Coleman-McCray JD, Martin BE, Nichol ST, Towner JS. Oral shedding of Marburg virus in experimentally infected Egyptian fruit bats (Rousettus aegyptiacus). J Wildl Dis. 2015 Jan;51(1):113-24. doi: 10.7589/2014-08-198. PubMed PMID: 25375951; PubMed Central PMCID: PMC5022530.

Bah EI, Lamah MC, Fletcher T, Jacob ST, Brett-Major DM, Sall AA, Shindo N,Fischer WA 2nd, Lamontagne F, Saliou SM, Bausch DG, Moumié B, Jagatic T, SprecherA, Lawler JV, Mayet T, Jacquerioz FA, Méndez Baggi MF, Vallenas C, Clement C, Mardel S, Faye O, Faye O, Soropogui B, Magassouba N, Koivogui L, Pinto R, Fowler RA. Clinical presentation of patients with Ebola virus disease in Conakry, Guinea. N Engl J Med. 2015 Jan 1;372(1):40-7. doi: 10.1056/NEJMoa1411249. Epub 2014 Nov 5. PubMed PMID: 25372658.

Bausch DG, Nichol ST, Muyembe-Tamfum JJ, Borchert M, Rollin PE, Sleurs H, Campbell P, Tshioko FK, Roth C, Colebunders R, Pirard P, Mardel S, Olinda LA, Zeller H, Tshomba A, Kulidri A, Libande ML, Mulangu S, Formenty P, Grein T, Leirs H, Braack L, Ksiazek T, Zaki S, Bowen MD, Smit SB, Leman PA, Burt FJ, Kemp A, Swanepoel R; International Scientific and Technical Committee for Marburg Hemorrhagic Fever Control in the Democratic Republic of the Congo. Marburg hemorrhagic fever associated with multiple genetic lineages of virus. N Engl J Med. 2006 Aug 31;355(9):909-19. PubMed PMID: 16943403.

Bell BP, Damon IK, Jernigan DB, et al. Overview, Control Strategies, and Lessons Learned in the CDC Response to the 2014 - 2016 Ebola Epidemic. MMWR Suppl 2016;65 (Suppl-3):4-11. doi:10.15585/mmwr.su6503a2.

Bwaka MA, Bonnet MJ, Calain P, Colebunders R, De Roo A, Guimard Y, Katwiki KR, Kibadi K, Kipasa MA, Kuvula KJ, Mapanda BB, Massamba M, Mupapa KD, Muyembe-Tamfum JJ, Ndaberey E, Peters CJ, Rollin PE, Van den Enden E, Van den Enden E. Ebola hemorrhagic fever in Kikwit, Democratic Republic of the Congo: clinical observations in 103 patients. J Infect Dis. 1999 Feb;179 Suppl 1:S1-7. PubMedPMID: 9988155.

Caron A, Bourgarel M, Cappelle J, Liégeois F, De Nys HM, Roger F. Ebola Virus Maintenance: If Not (Only) Bats, What Else? Viruses. 2018 Oct 9;10(10). pii: E549. doi: 10.3390/v10100549. Review. PubMed PMID: 30304789; PubMed Central PMCID: PMC6213544.

Clark DJ, Tyson J, Sails AD, Krishna S, Staines HM. The current landscape of nucleic acid tests for filovirus detection. J Clin Virol. 2018 Jun;103:27-36.doi: 10.1016/j.jcv.2018.03.005. Epub 2018 Mar 22. Review. PubMed PMID: 29625392; PubMed Central PMCID: PMC5958242.

Cnops L, Van den Eede P, Pettitt J, Heyndrickx L, De Smet B, Coppens S, Andries I, Pattery T, Van Hove L, Meersseman G, Van Den Herrewegen S, Vergauwe N, Thijs R, Jahrling PB, Nauwelaers D, Ariën KK. Development, Evaluation, and Integration of a Quantitative Reverse-Transcription Polymerase Chain Reaction Diagnostic Test for Ebola Virus on a Molecular Diagnostics Platform. J Infect Dis. 2016 Oct 15;214 (suppl 3):S192-S202. Epub 2016 May 30. PubMed PMID: 27247341; PubMed Central PMCID: PMC5050460.

Drosten C, Göttig S, Schilling S, Asper M, Panning M, Schmitz H, Günther S. Rapid detection and quantification of RNA of Ebola and Marburg viruses, Lassa virus, Crimean-Congo hemorrhagic fever virus, Rift Valley fever virus, dengue virus, and yellow fever virus by real-time reverse transcription-PCR. J Clin Microbiol. 2002 Jul;40(7):2323-30. PubMed PMID: 12089242; PubMed Central PMCID: PMC120575.

Emanuel J, Marzi A, Feldmann H. Filoviruses: Ecology, Molecular Biology, and Evolution. Adv Virus Res. 2018;100:189-221. doi: 10.1016/bs.aivir.2017.12.002. Epub 2018 Feb 1. Review. PubMed PMID: 29551136.

Feldmann H, Klenk HD, Sanchez A. Molecular biology and evolution of filoviruses. Arch Virol Suppl. 1993;7:81-100. Review. PubMed PMID: 8219816.

Feldmann H, Geisbert TW. Ebola haemorrhagic fever. Lancet. 2011 Mar5;377(9768):849-62. doi: 10.1016/S0140-6736(10)60667-8. Review. PubMed PMID:21084112; PubMed Central PMCID: PMC3406178.

Gibb TR, Norwood DA Jr, Woollen N, Henchal EA. Development and evaluation of a fluorogenic 5'-nuclease assay to identify Marburg virus. Mol Cell Probes. 2001 Oct;15(5):259-66. PubMed PMID: 11735297. 
Gire SK, Goba A, Andersen KG, Sealfon RS, Park DJ, Kanneh L, Jalloh S, Momoh M, Fullah M, Dudas G, Wohl S, Moses LM, Yozwiak NL, Winnicki S, Matranga CB, Malboeuf CM, Qu J, Gladden AD, Schaffner SF, Yang X, Jiang PP, Nekoui M, Colubri A, Coomber MR, Fonnie M, Moigboi A, Gbakie M, Kamara FK, Tucker V, Konuwa E, Saffa S, Sellu J, Jalloh AA, Kovoma A, Koninga J, Mustapha I, Kargbo K, Foday M, Yillah M, Kanneh F, Robert W, Massally JL, Chapman SB, Bochicchio J, Murphy C, Nusbaum C, Young S, Birren BW, Grant DS, Scheiffelin JS, Lander ES, Happi C, Gevao SM, Gnirke A, Rambaut A, Garry RF, Khan SH, Sabeti PC. Genomic surveillance elucidates Ebola virus origin and transmission during the 2014 outbreak. Science. 2014 Sep 12;345(6202):1369-72. doi: 10.1126/science.1259657. Epub 2014 Aug 28. PubMed PMID: 25214632; PubMed Central PMCID: PMC4431643.

Goldstein T, Anthony SJ, Gbakima A, Bird BH, Bangura J, Tremeau-Bravard A, Belaganahalli MN, Wells HL, Dhanota JK, Liang E, Grodus M, Jangra RK, DeJesus VA, Lasso G, Smith BR, Jambai A, Kamara BO, Kamara S, Bangura W, Monagin C, Shapira S, Johnson CK, Saylors K, Rubin EM, Chandran K, Lipkin WI, Mazet JAK. The discovery of Bombali virus adds further support for bats as hosts of ebolaviruses. Nat Microbiol. 2018 Oct;3(10):1084-1089. doi: 10.1038/s41564-018-0227-2. Epub 2018 Aug 27. Erratum in: Nat Microbiol. 2018 Dec;3(12):1486. PubMed PMID: 30150734.

Gonzalez JP, Pourrut X, Leroy E. Ebolavirus and other filoviruses. Curr Top Microbiol Immunol. 2007;315:36387. Review.

Groseth A, Ströher U, Theriault S, Feldmann H. Molecular characterization of an isolate from the 1989/90 epizootic of Ebola virus Reston among macaques imported into the United States. Virus Res. 2002 Aug;87(2):155-63. PubMed PMID:12191779.

He B, Feng Y, Zhang H, Xu L, Yang W, Zhang Y, Li X, Tu C. Filovirus RNA in Fruit Bats, China. Emerg Infect Dis. 2015 Sep;21(9):1675-7. doi:10.3201/eid2109.150260. PubMed PMID: 26291173; PubMed Central PMCID: PMC4550138.

Karesh WB, Dobson A, Lloyd-Smith JO, Lubroth J, Dixon MA, Bennett M, Aldrich S, Harrington T, Formenty P, Loh EH, Machalaba CC, Thomas MJ, Heymann DL. Ecology of zoonoses: natural and unnatural histories. Lancet. 2012 Dec 1;380(9857):1936-45. doi: 10.1016/S0140-6736(12)61678-X. Review. PubMed PMID: 23200502.

Leroy EM, Telfer P, Kumulungui B, Yaba P, Rouquet P, Roques P, Gonzalez JP, Ksiazek TG, Rollin PE, Nerrienet E. A serological survey of Ebola virus infection in central African nonhuman primates. J Infect Dis. 2004 Dec 1;190(11):1895-9. Epub 2004 Nov 3. PubMed PMID: 15529251.

Loftis AJ, Quellie S, Chason K, Sumo E, Toukolon M, Otieno Y, Ellerbrok H, Hobbs MM, Hoover D, Dube K, Wohl DA, Fischer WA 2nd. Validation of the Cepheid GeneXpert for Detecting Ebola Virus in Semen. J Infect Dis. 2017 Feb 1;215(3):344-350. doi: 10.1093/infdis/jiw562. PubMed PMID: 27932614; PubMed Central PMCID: PMC5965086.

MacNeil A, Farnon EC, Wamala J, Okware S, Cannon DL, Reed Z, Towner JS, Tappero JW, Lutwama J, Downing R, Nichol ST, Ksiazek TG, Rollin PE. Proportion of deaths and clinical features in Bundibugyo Ebola virus infection, Uganda. Emerg Infect Dis. 2010 Dec;16(12):1969-72. doi: 10.3201/eid1612.100627. PubMed PMID:21122234; PubMed Central PMCID: PMC3294552.

Marí Saéz A, Weiss S, Nowak K, Lapeyre V, Zimmermann F, Düx A, Kühl HS, Kaba M, Regnaut S, Merkel K, Sachse A, Thiesen U, Villányi L, Boesch C, Dabrowski PW, Radonić A, Nitsche A, Leendertz SA, Petterson S, Becker S, Krähling V, Couacy-Hymann E, Akoua-Koffi C, Weber N, Schaade L, Fahr J, Borchert M, Gogarten JF, Calvignac-Spencer S, Leendertz FH. Investigating the zoonotic origin of the West African Ebola epidemic. EMBO Mol Med. 2015 Jan;7(1):17-23. doi: 10.15252/emmm.201404792. PubMed PMID: 25550396; PubMed Central PMCID: PMC4309665.

McElroy A. Understanding bleeding in ebola virus disease. Clin Adv Hematol Oncol. 2015 Jan;13(1):29-31. PubMed PMID: 25679971; PubMed Central PMCID: PMC4667727. 
Ministere de la Sante de Republique Democratique du Congo (RDC). Communique de Presse. Le Comité éthique approuve le protocole de l'essai clinique randomisé des traitements thérapeutiques expérimentaux contre Ebola. Kinshasa, 24 novembre 2018. [French, Internet, accessed 21 Feb 2019]. Available from: https://mailchi.mp/sante.gouv.cd/ebola kivu essais cliniques?e=dbcc6766ca.

Miraglia CM. Marburgviruses: An Update. Lab Med. 2019 Jan 1;50(1):16-28. doi: 10.1093/labmed/lmy046. Review. PubMed PMID: 30085179.

Mylne A, Brady OJ, Huang Z, Pigott DM, Golding N, Kraemer MU, Hay SI. A comprehensive database of the geographic spread of past human Ebola outbreaks. Sci Data. 2014 Oct 23;1:140042. doi: 10.1038/sdata.2014.42. eCollection 2014. PubMed PMID: 25984346; PubMed Central PMCID: PMC4432636.

National Institutes of Health Clinical Center (NIHCC). National Institute of Allergy and Infectious Diseases (NIAID). Investigational Therapeutics for the Treatment of People With Ebola Virus Disease. 25 Oct 2018. Updated 21 Feb 2019. [Internet, accessed 21 Feb 2019]. Available from:

https://clinicaltrials.gov/ct2/show/NCT03719586.

Ogawa H, Miyamoto H, Ebihara H, Ito K, Morikawa S, Feldmann H, Takada A. Detection of all known filovirus species by reverse transcription-polymerase chain reaction using a primer set specific for the viral nucleoprotein gene. J Virol Methods. 2011 Jan;171(1):310-3. doi: 10.1016/j.jviromet.2010.11.010. Epub 2010 Nov 17. PubMed PMID: 21093485; PubMed Central PMCID: PMC3393132.

Okware SI, Omaswa FG, Zaramba S, Opio A, Lutwama JJ, Kamugisha J, Rwaguma EB, Kagwa P, Lamunu M. An outbreak of Ebola in Uganda. Trop Med Int Health. 2002 Dec;7(12):1068-75. PubMed PMID: 12460399.

Panning M, Laue T, Olschlager S, Eickmann M, Becker S, Raith S, Courbot MC, Nilsson M, Gopal R, Lundkvist A, di Caro A, Brown D, Meyer H, Lloyd G, Kummerer BM, Gunther S, Drosten C. Diagnostic reversetranscription polymerase chain reaction kit for filoviruses based on the strain collections of all European biosafety level 4 laboratories. J Infect Dis. 2007 Nov 15;196 Suppl 2:S199-204. PubMed PMID: 17940950.

Paweska JT, Jansen van Vuren P, Masumu J, Leman PA, Grobbelaar AA, Birkhead M, Clift S, Swanepoel R, Kemp A. Virological and serological findings in Rousettus aegyptiacus experimentally inoculated with vero cells-adapted hogan strain of Marburg virus. PLoS One. 2012;7(9):e45479. doi: 10.1371/journal.pone.0045479. Epub 2012 Sep 17. PubMed PMID: 23029039; PubMed Central PMCID: PMC3444458.

Paweska JT, Jansen van Vuren P, Fenton KA, Graves K, Grobbelaar AA, Moolla N, Leman P, Weyer J, Storm N, McCulloch SD, Scott TP, Markotter W, Odendaal L, Clift SJ, Geisbert TW, Hale MJ, Kemp A. Lack of Marburg Virus Transmission From Experimentally Infected to Susceptible In-Contact Egyptian Fruit Bats. J Infect Dis. 2015 Oct 1;212 Suppl 2:S109-18. doi: 10.1093/infdis/jiv132. Epub 2015 Apr 2. PubMed PMID: 25838270.

Peters CJ, Khan AS. Filovirus diseases. In: Klenk H-D, editor. Current topics in microbiology and immunology: Marburg and Ebola viruses. Vol. 235. Berlin: Springer; 1999. pp. 85-95.

Pettitt J, Higgs E, Fallah M, Nason M, Stavale E, Marchand J, Reilly C, Jensen K, Dighero-Kemp B, Tuznik K, Logue J, Bolay F, Hensley L. Assessment and Optimization of the GeneXpert Diagnostic Platform for Detection of Ebola Virus RNA in Seminal Fluid. J Infect Dis. 2017 Feb 15;215(4):547-553. doi: 10.1093/infdis/jiw599. PubMed PMID: 28003349; PubMed Central PMCID: PMC6075475.

Pigott DM, Golding N, Mylne A, Huang Z, Henry AJ, Weiss DJ, Brady OJ, Kraemer MU, Smith DL, Moyes CL, Bhatt S, Gething PW, Horby PW, Bogoch II, Brownstein JS, Mekaru SR, Tatem AJ, Khan K, Hay SI. Mapping the zoonotic niche of Ebola virus disease in Africa. Elife. 2014 Sep 8;3:e04395. doi: 10.7554/eLife.04395. PubMed PMID: 25201877; PubMed Central PMCID: PMC4166725.

Pigott DM, Golding N, Mylne A, Huang Z, Weiss DJ, Brady OJ, Kraemer MU, Hay SI. Mapping the zoonotic niche of Marburg virus disease in Africa. Trans R Soc Trop Med Hyg. 2015 Jun;109(6):366-78. doi: 10.1093/trstmh/trv024. Epub 2015 Mar 27. Review. PubMed PMID: 25820266; PubMed Central PMCID: PMC4447827. 
Pinsky BA, Sahoo MK, Sandlund J, Kleman M, Kulkarni M, Grufman P, Nygren M, Kwiatkowski R, Baron EJ, Tenover F, Denison B, Higuchi R, Van Atta R, Beer NR, Carrillo AC, Naraghi-Arani P, Mire CE, Ranadheera C, Grolla A, Lagerqvist N, Persing DH. Analytical Performance Characteristics of the Cepheid GeneXpert Ebola Assay for the Detection of Ebola Virus. PLoS One. 2015 Nov 12;10(11):e0142216. doi: 10.1371/journal.pone.0142216. eCollection 2015. Erratum in: PLoS One. 2015;10(12):e0145896. PubMed PMID: 26562786; PubMed Central PMCID: PMC4643052.

Pittman PR, Brown ES, Chambers MS. Medical Countermeasures. pp. 751-821. In: Medical Aspects of Biological Warfare. Textbooks of military medicine. Eds.: Bozue J, Cote CK, Glass PJ. Fort Sam Houston, Texas: Office of the Surgeon General, Borden Institute, US Army Medical Department Center and School, Health, Readiness Center of Excellence. 2018. LCCN 2017057681. ISBN 9780160941597.

Rieger T, Kerber R, El Halas H, Pallasch E, Duraffour S, Günther S, Ölschläger S. Evaluation of RealStar Reverse Transcription-Polymerase Chain Reaction Kits for Filovirus Detection in the Laboratory and Field. J Infect Dis. 2016 Oct 15;214(suppl 3):S243-S249. Epub 2016 Aug 21. PubMed PMID: 27549586; PubMed Central PMCID: PMC5050472.

Roddy P, Thomas SL, Jeffs B, Nascimento Folo P, Pablo Palma P, Moco HenriqueB, Villa L, Damiao Machado FP, Bernal O, Jones SM, Strong JE, Feldmann H,Borchert M. Factors associated with Marburg hemorrhagic fever: analysis of patient data from Uige, Angola. J Infect Dis. 2010 Jun 15;201(12):1909-18. doi:10.1086/652748. PubMed PMID: 20441515; PubMed Central PMCID: PMC3407405.

Rougeron V, Feldmann H, Grard G, Becker S, Leroy EM. Ebola and Marburg haemorrhagic fever. J Clin Virol. 2015 Mar;64:111-9. doi:10.1016/j.jcv.2015.01.014. Epub 2015 Jan 23. Review. PubMed PMID: 25660265.

Rouquet P, Froment JM, Bermejo M, Kilbourn A, Karesh W, Reed P, Kumulungui B, Yaba P, Délicat A, Rollin PE, Leroy EM. Wild animal mortality monitoring and human Ebola outbreaks, Gabon and Republic of Congo, 2001-2003. Emerg Infect Dis. 2005 Feb;11(2):283-90. PubMed PMID: 15752448; PubMed Central PMCID: PMC3320460.

Sanchez A, Ksiazek TG, Rollin PE, Miranda ME, Trappier SG, Khan AS, Peters CJ, Nichol ST. Detection and molecular characterization of Ebola viruses causing disease in human and nonhuman primates. J Infect Dis. 1999 Feb;179 Suppl 1:S164-9. PubMed PMID: 9988180.

Schieffelin JS, Shaffer JG, Goba A, Gbakie M, Gire SK, Colubri A, Sealfon RS, Kanneh L, Moigboi A, Momoh M, Fullah M, Moses LM, Brown BL, Andersen KG, Winnicki S, Schaffner SF, Park DJ, Yozwiak NL, Jiang PP, Kargbo D, Jalloh S, Fonnie M,Sinnah V, French I, Kovoma A, Kamara FK, Tucker V, Konuwa E, Sellu J, Mustapha I, Foday M, Yillah M, Kanneh F, Saffa S, Massally JL, Boisen ML, Branco LM, VandiMA, Grant DS, Happi C, Gevao SM, Fletcher TE, Fowler RA, Bausch DG, Sabeti PC, Khan SH, Garry RF; KGH Lassa Fever Program; Viral Hemorrhagic Fever Consortium; WHO Clinical Response Team. Clinical illness and outcomes in patients with Ebola in Sierra Leone. N Engl J Med. 2014 Nov 27;371(22):2092-100.

doi:10.1056/NEJMoa1411680. Epub 2014 Oct 29. PubMed PMID: 25353969; PubMed CentralPMCID: PMC4318555.

Semper AE, Broadhurst MJ, Richards J, Foster GM, Simpson AJ, Logue CH, Kelly JD, Miller A, Brooks TJ, Murray M, Pollock NR. Performance of the GeneXpert Ebola Assay for Diagnosis of Ebola Virus Disease in Sierra Leone: A Field Evaluation Study. PLoS Med. 2016 Mar 29;13(3):e1001980. doi:

10.1371/journal.pmed.1001980. eCollection 2016 Mar. PubMed PMID: 27023868; PubMed Central PMCID: PMC4811569.

Southern TR, Racsa LD, Albariño CG, Fey PD, Hinrichs SH, Murphy CN, Herrera VL, Sambol AR, Hill CE, Ryan EL, Kraft CS, Campbell S, Sealy TK, Schuh A, Ritchie JC, Lyon GM 3rd, Mehta AK, Varkey JB, Ribner BS, Brantly KP, Ströher U, Iwen PC, Burd EM. Comparison of FilmArray and Quantitative Real-Time Reverse Transcriptase PCR for Detection of Zaire Ebolavirus from Contrived and Clinical Specimens. J Clin Microbiol. 2015 Sep;53(9):2956-60. doi: 10.1128/JCM.01317-15. Epub 2015 Jul 8. PubMed PMID: 26157148; PubMed Central PMCID: PMC4540924. 
TIB MolBiol, Roche. LightMix® Ebola Zaire rRT-PCR Test. (n.d.). [Internet, accessed 21 Feb 2019]. Available from: https://www.fda.gov/downloads/MedicalDevices/Safety/EmergencySituations/UCM428004.pdf.

Towner JS, Rollin PE, Bausch DG, Sanchez A, Crary SM, Vincent M, Lee WF, Spiropoulou CF, Ksiazek TG, Lukwiya M, Kaducu F, Downing R, Nichol ST. Rapid diagnosis of Ebola hemorrhagic fever by reverse transcription-PCR in an outbreak setting and assessment of patient viral load as a predictor of outcome. J Virol. 2004 Apr;78(8):4330-41. PubMed PMID: 15047846; PubMed Central PMCID: PMC374287.

Towner JS, Khristova ML, Sealy TK, et al. Marburgvirus genomics and association with a large hemorrhagic fever outbreak in Angola. Journal of Virology. 2006;80(13):6497-6516.

Towner JS, Sealy TK, Khristova ML, Albariño CG, Conlan S, Reeder SA, Quan PL, Lipkin WI, Downing R, Tappero JW, Okware S, Lutwama J, Bakamutumaho B, Kayiwa J, Comer JA, Rollin PE, Ksiazek TG, Nichol ST. Newly discovered ebola virus associated with hemorrhagic fever outbreak in Uganda. PLoS Pathog. 2008 Nov;4(11):e1000212. doi: 10.1371/journal.ppat.1000212. Epub 2008 Nov 21. PubMed PMID: 19023410; PubMed Central PMCID: PMC2581435.

Towner JS, Amman BR, Sealy TK, Carroll SA, Comer JA, Kemp A, Swanepoel R, Paddock CD, Balinandi S, Khristova ML, Formenty PB, Albarino CG, Miller DM, Reed ZD, Kayiwa JT, Mills JN, Cannon DL, Greer PW, Byaruhanga E, Farnon EC, Atimnedi P, Okware S, Katongole-Mbidde E, Downing R, Tappero JW, Zaki SR, Ksiazek TG, Nichol ST, Rollin PE. Isolation of genetically diverse Marburg viruses from Egyptian fruit bats. PLoS Pathog. 2009 Jul;5(7):e1000536.

Trombley AR, Wachter L, Garrison J, Buckley-Beason VA, Jahrling J, Hensley LE, Schoepp RJ, Norwood DA, Goba A, Fair JN, Kulesh DA. Comprehensive panel of real-time TaqMan polymerase chain reaction assays for detection and absolute quantification of filoviruses, arenaviruses, and New World hantaviruses. Am J Trop Med Hyg. 2010 May;82(5):954-60. doi: 10.4269/ajtmh.2010.09-0636. PubMed PMID: 20439981; PubMed Central PMCID: PMC2861391.

U.S. Food and Drug Administration (FDA). EZ1 EUO Authorisation. 2014 Oct 10. [Internet, accessed 21 Feb 2019]. Available from:

https://www.fda.gov/downloads/MedicalDevices/Safety/EmergencySituations/UCM418799.pdf.

Warren TK, Wells J, Panchal RG, et al. Protection against filovirus diseases by a novel broad-spectrum nucleoside analogue BCX4430. Nature. 2014;508:402-405.

Waterhouse AM, Procter JB, Martin DM, Clamp M, Barton GJ. Jalview Version 2 - a multiple sequence alignment editor and analysis workbench. Bioinformatics. 2009 May 1;25(9):1189-91. doi:

10.1093/bioinformatics/btp033. Epub 2009 Jan 16. PubMedPMID: 19151095; PubMed Central PMCID: PMC2672624.

Weidmann M, Mühlberger E, Hufert FT. Rapid detection protocol for filoviruses. J Clin Virol. 2004 May;30(1):94-9. PubMed PMID: 15072761.

Wittmann TJ, Biek R, Hassanin A, Rouquet P, Reed P, Yaba P, Pourrut X, Real LA, Gonzalez JP, Leroy EM. Isolates of Zaire ebolavirus from wild apes reveal genetic lineage and recombinants. Proc Natl Acad Sci U S A. 2007 Oct 23;104(43):17123-7. Epub 2007 Oct 17. Erratum in: Proc Natl Acad Sci U S A. 2007 Dec 4;104(49):19656. PubMed PMID: 17942693; PubMed Central PMCID: PMC2040453.

World Health Organization (WHO). Ebola haemorrhagic fever in Zaire, 1976. Bull World Health Organ.1978;56(2):271-93. PubMed PMID: 307456; PubMed Central PMCID: PMC2395567.

World Health Organization (WHO). WHO Emergency Use Assessment and Listing Procedure for EVD IVDs PUBLIC REPORT, Product: LiferiverTM - Ebola Virus (EBOV) Real Time RT-PCR Kit, Number: EA 0009009-00. Apr 2015. [Internet, accessed 21 Feb 2019]. Available from: http://www.who.int/diagnostics laboratory/procurement/150427 liferiver china public report.pdf 
bioRxiv preprint doi: https://doi.org/10.1101/579458; this version posted March 16, 2019. The copyright holder for this preprint (which was not certified by peer review) is the author/funder, who has granted bioRxiv a license to display the preprint in perpetuity. It is made available under aCC-BY-NC-ND 4.0 International license.

World Health Organization (WHO). Notes for the record: Consultation on Monitored Emergency Use of Unregistered and Investigational Interventions for Ebola Virus Disease (EVD). 17 May 2018. [Internet, accessed 21 Feb 2019]. Available from: https://www.who.int/emergencies/ebola/MEURI-Ebola.pdf.

World Health Organization (WHO). Ebola treatments approved for compassionate use in current outbreak. 6 Jun 2018. [Internet, accessed 21 Feb 2019]. Available from: http://www.who.int/ebola/drc-2018/treatmentsapproved-for-compassionate-use/en/.

World Health Organization (WHO). Ebola virus disease. Frequently asked questions on Ebola virus disease. Updated 30 Oct 2018. [Internet, accessed 21 Feb 2019]. Available from: http://www.who.int/ebola/drc-2018/faqvaccine/en/.

Yang XL, Zhang YZ, Jiang RD, Guo H, Zhang W, Li B, Wang N, Wang L, Waruhiu C, Zhou JH, Li SY, Daszak P, Wang LF, Shi ZL. Genetically Diverse Filoviruses in Rousettus and Eonycteris spp. Bats, China, 2009 and 2015. Emerg Infect Dis. 2017 Mar;23(3):482-486. doi: 10.3201/eid2303.161119. PubMed PMID: 28221123; PubMedCentral PMCID: PMC5382765.

Yang XL, Tan CW, Anderson DE, Jiang RD, Li B, Zhang W, Zhu Y, Lim XF, Zhou P, Liu XL, Guan W, Zhang L, Li SY, Zhang YZ, Wang LF, Shi ZL. Characterization of a filovirus (Měnglà virus) from Rousettus bats in China. Nat Microbiol. 2019 Jan 7. doi: 10.1038/s41564-018-0328-y. [Epub ahead of print] Erratum in: Nat Microbiol. 2019 Feb 8;:. PubMed PMID: 30617348.

Ye J, Coulouris G, Zaretskaya I, Cutcutache I, Rozen S, Madden TL. Primer-BLAST: a tool to design targetspecific primers for polymerase chain reaction. BMC Bioinformatics. 2012 Jun 18;13:134. doi: 10.1186/14712105-13-134. PubMed PMID: 22708584; PubMed Central PMCID: PMC3412702.

Zhai J, Palacios G, Towner JS, Jabado O, Kapoor V, Venter M, Grolla A, Briese T, Paweska J, Swanepoel R, Feldmann H, Nichol ST, Lipkin WI. Rapid molecular strategy for filovirus detection and characterization. J Clin Microbiol. 2007 Jan;45(1):224-6. Epub 2006 Nov 1. PubMed PMID: 17079496; PubMed Central PMCID: PMC1828965. 